\title{
HEAVY ION BEAM PROBING CONCEPTUAL DESIGN FOR THE GLOBUS-M2 TOKAMAK
}

\author{
Ph.O. Khabanov ${ }^{1}$, A.V. Melnikov ${ }^{1,2}$, V.B. Minaev ${ }^{3}$, A.D. Komarov ${ }^{4}$ \\ ${ }^{1}$ NRC “Kurchatov Institute”, Moscow, Russia; \\ ${ }^{2}$ National Research Nuclear University “MEPhI”, Moscow, Russia; \\ ${ }^{3}$ Ioffe Institute, St. Petersburg, Russia; \\ ${ }^{4}$ Institute of Plasma Physics NSC “Kharkov Institute of Physics and Technology", Kharkiv, Ukraine
}

\section{E-mail:khabanov@phystech.edu}

The paper discusses the application of the heavy ion beam probe (HIBP) diagnostic to the Globus-M2 spherical tokamak. Probing beam trajectory calculations were conducted to find the optimal position for HIBP primary and secondary beam-linesin the realistic machine geometry. Three configurations of the vacuum vessel ports of Globus-M2 were considered for the regime with toroidal magnetic field $\mathrm{B}_{\text {tor }}=0.7 \mathrm{~T}$ and plasma current $\mathrm{I}_{\mathrm{pl}}=0.5 \mathrm{MA}$. The optimal probing scheme with the widest area of the plasma cross-section covered by the detector grid was selected. For this scheme, the secondary beam-line was proposed.

PACS: 02.60.Cb, 52.70. $-\mathrm{m}, 52.55 . \mathrm{Fa}, 52.70 . \mathrm{Nc}$

\section{INTRODUCTION}

Modern experimental studies of turbulent transport in fusion devices such as tokamaks and stellarators require advanced diagnostic techniques, which could allow measurements of electric fields and electrostatic turbulence properties in bulk plasmas [1]. Heavy Ion Beam Probe (HIBP) is an advanced fusion plasma diagnostic technique to measure local plasma electrostatic potential and its fluctuations inside the plasma column. The method is based on launching into the plasma a beam of single-charged metal ions (primary beam, $\mathrm{Cs}^{+}, \mathrm{Tl}^{+}, \mathrm{K}^{+}, \mathrm{Na}^{+}$) perpendicular to the confining magnetic field of the device and collecting doubly-charged secondary ions, which were born inside the plasma due to electron-impact ionization of the primary ions [2]. In addition to plasma potential, the method allows studying local electron density fluctuations, and if equipped with multichannel detection system, opens a way to correlation analysis of turbulence properties [3-5].

HIBP has been successfully implemented on many fusion devices, both stellarators (LHD, TJ-II, CHS, Uragan-2M) and tokamaks (TEXT, T-10, JIPPTII-U, ISTOK). On TJ-II stellarator HIBP was successfully used for Alfven eigen modes studies [6, 7], on T-10 tokamak it was used for studies of Geodesic Acoustic Modes (GAM) [8], on stellarators CHS and TJ-II it was also used for the electron density profile measurements $[9,10]$.

The Globus-M2 spherical tokamak is the upgraded Globus-M machine (major radius $\mathrm{R}=0.36 \mathrm{~m}$, minor radius $\mathrm{a}=0.24 \mathrm{~m}$ ), which was launched in 2018 at the Ioffe Institute in St. Petersburg, Russia. The machine upgrade was focused on the increase of the toroidal magnetic field $\mathrm{B}_{\text {tor }}$ from 0.4 up to $1 \mathrm{~T}$ and plasma current $I_{p l}$ from 0.2 up to 0.5 MA [11]. For now the working shots with $\mathrm{B}_{\text {tor }}=0.5 \mathrm{~T}, \mathrm{I}_{\mathrm{pl}}=0.15 \mathrm{MA}$ have been obtained [12]. The Globus-M2 project is aimed at the research of the non-inductive current drive and plasma heating in low aspect ratio magnetic configurations. The use of HIBP diagnostic on Globus-M2 will provide important information on plasma electric potential and turbulence behavior during these scenarios.

It has been shown earlier, that the HIBP diagnostic is applicable for the Globus-M tokamak [13], but it has never been implemented. The aim of the current paper is the feasibility study of HIBP for the upgraded Globus-M2 spherical tokamak.

\section{NUMERICAL MODEL DESCRIPTION}

HIBP conceptual design implies computational research of optimal positionsfor primary and secondary beam-lines on the fusion device. Probing ion trajectories in the magnetic field of Globus-M2 tokamak were calculated using the Python code, developed during HIBP design for T-15MD tokamak[14, 15]. The Cartesian coordinate systemwith Y-axis directed along the major axis of the torus was used in numerical simulations; it is shown in Fig. 1.

As a reference scenario, the so-called "t-max" regime with toroidal magnetic field $\mathrm{B}_{\text {tor }}=0.7 \mathrm{~T}$ and plasma current $\mathrm{I}_{\mathrm{pl}}=0.5 \mathrm{MA}$ was chosen [16].

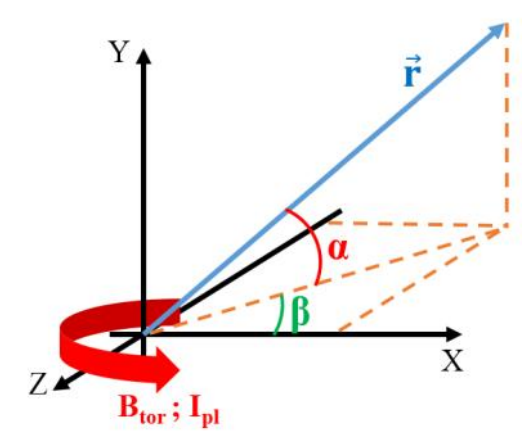

Fig. 1. Cartesian coordinate system used for calculations. The center is located on the major axis of the torus. $B_{\text {tor }}$ - toroidal magnetic field of a tokamak, $I_{p l}$ - plasma current 
Plasma current distribution was set in a simple elliptic approximation with elongation $\mathrm{k}=1.8$ :

$j(\rho)=1 /\left(1+\left(\rho / a_{j}\right)^{2}\right)^{2} ; \rho^{2}=\left(\frac{x-R}{a}\right)^{2}+\left(\frac{y}{k a}\right)^{2}$,

$a_{j}=a \sqrt{\left(q_{0} /\left(q_{a}-q_{0}\right)\right)}$,

$q_{0}=1 ; q_{a}=\frac{5 B_{\text {tor }}[T] a^{2}\left[\mathrm{~m}^{2}\right]}{I_{p l}[M A] R[\mathrm{~m}]}$.

This simple model is good enough to quantify the secondary beam shift in the toroidal direction due to plasma current magnetic field.

The example of HIBP trajectory for $\mathrm{Cs}^{+}$probing beam $\left(\mathrm{E}_{\text {beam }}=40 \mathrm{keV}\right)$ with a fan of $\mathrm{Cs}^{2+}$ secondary ions is shown in Fig. 2. Here and below primary trajectories are shown in black and secondary trajectories are shown in red. Infinitely thin trajectories were calculated for a single ion. Two pairs of deflecting plates in the primary beam-line control $\alpha$ and $\beta$ angles of the primary beam: $\alpha$-plates are sweeping plates; they are used to change the injection angle within the vertical plane, $\beta$-plates - to compensate toroidal displacement of the beam. Sizes of all plates are the same $(0.15 \times 0.05 \mathrm{~m})$ and the distance between the plates is $0.05 \mathrm{~m}$.

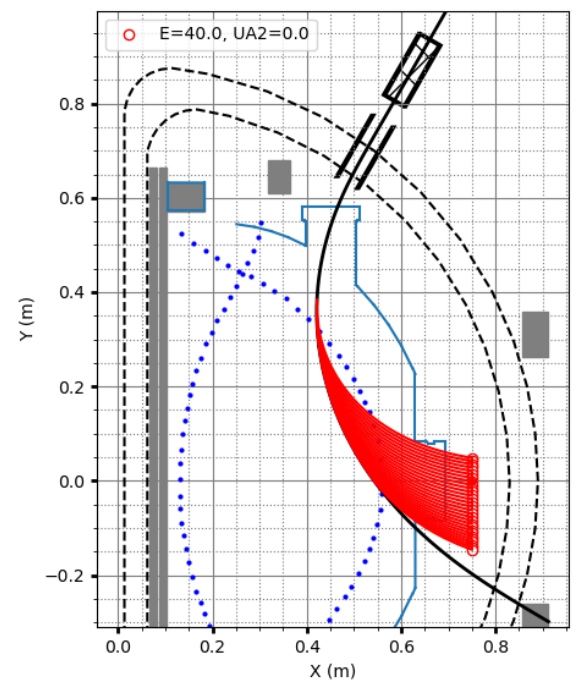

Fig. 2. HIBP trajectories at the vertical cut of GlobusM2 tokamak. Probing scheme 1 ( $90^{\circ}$ input port). Beam energy $E_{\text {beam }}=40 \mathrm{keV}$. Two pairs of deflecting plates control $\alpha$ and $\beta$ angles of the primary beam. Beam trajectories: black-primary, red-secondary. Blue dots represent the contour of plasma separatrix [16]

\section{VARIOUS PROBING SCHEMES}

By varying the probing beam energy, $\mathrm{E}_{\text {beam }}$, and the injection angle one can shift the HIBP sample volume (SV) across the plasma column. A set of SVs corresponding to the fixed value of $\mathrm{E}_{\text {beam }}$ and several values of the injection angle forms the detector line, while several detector lines for various $E_{\text {beam }}$ form a detector grid, which shows the area of the plasma crosssection accessible for HIBP measurements. The main target for the optimization was to choose the position of the primary and secondary beam-lines in order to maximize the plasma cross section area covered by the detector grid. Three Globus-M2 vacuum vessel port combinations (pairs) were considered. Three ports, used for the beam injection have the following angles with the horizon: $90^{\circ}$ (Probing scheme 1), $25^{\circ}$ (Probing scheme 2) and $78^{\circ}$ (Probing scheme 3 ). The detection point was placed at the exit of the horizontal port at $(\mathrm{x}, \mathrm{y}, \mathrm{z})=(0.75,0,0)$, all linear dimensions in $\mathrm{m}$.

Fig. 3 shows the detector line for the probing scheme 1 with the $40 \mathrm{keV} \mathrm{Cs}{ }^{+}$probing beam injected through the $90^{\circ}$ port. The angle $\alpha$ of the primary beamline was set to $60^{\circ}$ in order to push the detector line deeper into the plasma, and the toroidal angle $\beta$ was set to $-5^{\circ}$ to reduce the effect of the beam toroidal displacement due to plasma current. To get the detector line the beam injection angle $(\alpha)$ was varied by changing the voltage applied between the $\alpha$-plates. The $\mathrm{SVs}$ for each $\alpha$ angle value are marked by closed red dots.
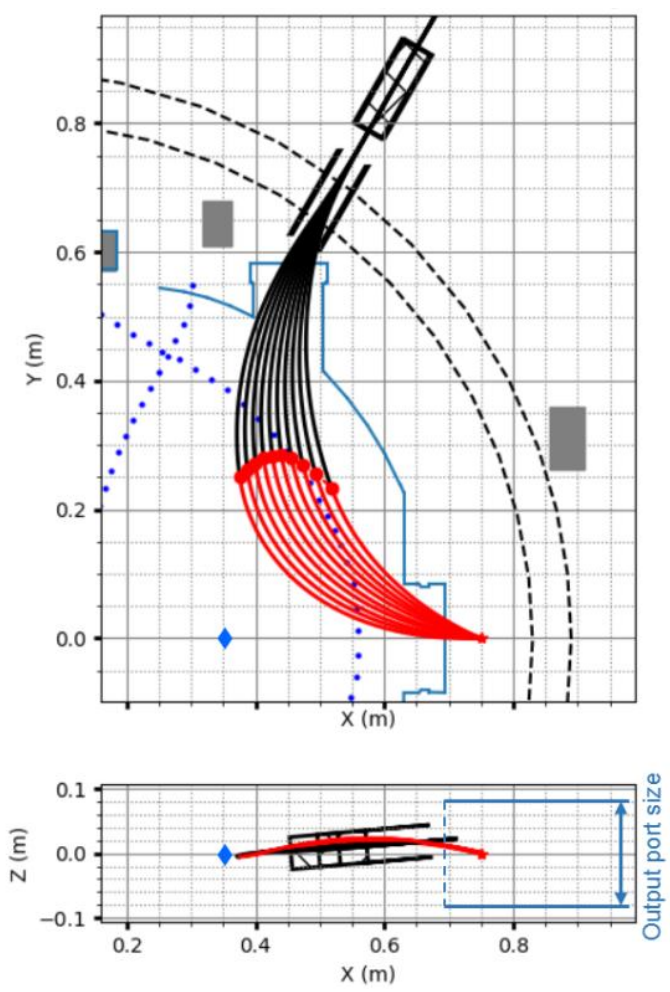

Fig. 3. HIBP detector line for the probing scheme 1 $\left(90^{\circ}\right.$ input port $), E_{\text {beam }}=40 \mathrm{keV}$. Primary beam-line angles are $\alpha=60^{\circ}, \beta=-5^{\circ}$. Top: side view, bottom: bottom view. Red star denotes the detection point, blue diamond denotes plasma center

It should be noted, that in this case, despite the high value of plasma current, the toroidal displacement of the beam is rather small and allows adjusting secondary trajectories to the detection point using $\beta$-plates. Fig. 4 shows the detector grid, obtained for the $\mathrm{Cs}^{+}$beam with $\mathrm{E}_{\text {beam }}=25 \ldots 50 \mathrm{keV}$ injected through the $90^{\circ}$ port. The beam energy is shown in the legend, detector lines of the equal energy are marked with solid lines, and detector lines of the equal injection angle are marked with dash lines. The voltage, applied between the sweeping plates ( $\alpha$-plates), represents the injection 
angle. Detector lines connect plasma periphery with the plasma core up to $\mathrm{R}=0.35 \mathrm{~m}$, which will allow to investigate the evolution of plasma potential profile in a much wider radial range than, for example, Langmuir probes.

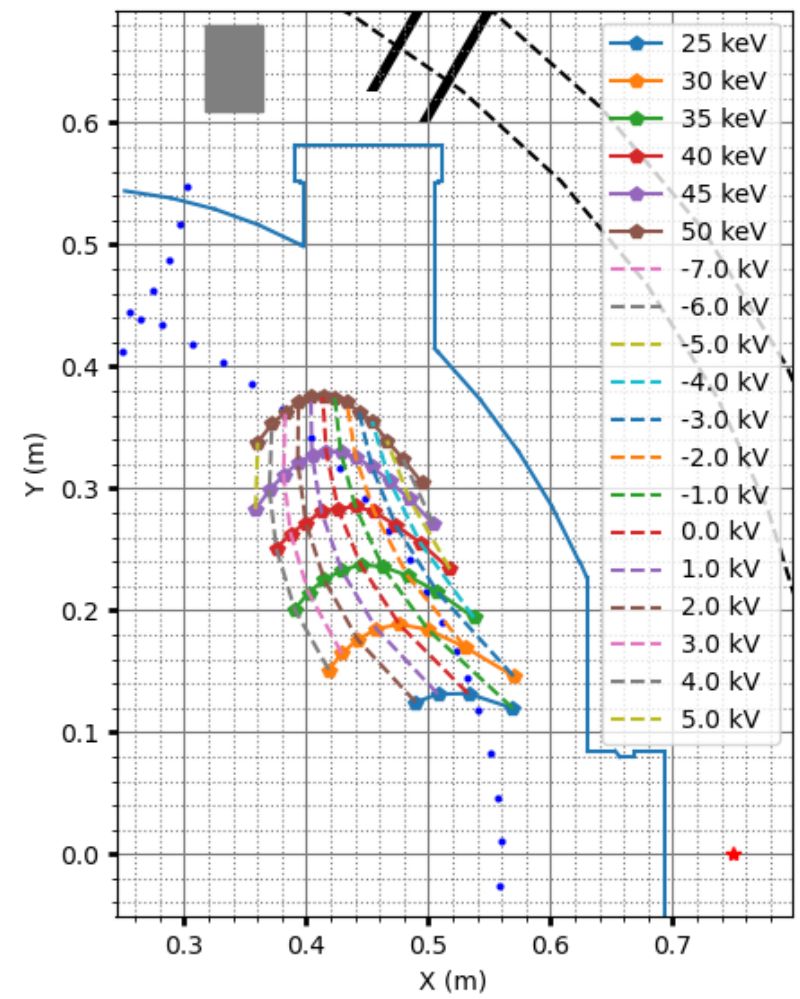

Fig. 4. Detector grid for the probing scheme 1 $\left(90^{\circ}\right.$ input port). Primary beam-line angles are $\alpha=60^{\circ}$, $\beta=-5^{\circ}$. Solid lines are lines of the equal energy, dashed lines are lines of the equal injection angle, represented by the voltage, applied between the $\alpha$-plates

Fig. 5 shows the detector line for $\mathrm{Cs}^{+}$probing beam with $\mathrm{E}_{\text {beam }}=40 \mathrm{keV}$ injected through the $25^{\circ}$ port. Fig. 6 shows the corresponding detector grid with $\mathrm{E}_{\text {beam }}=25 \ldots 50 \mathrm{keV}$. In this case, the toroidal shift is larger, so the angle $\beta$ is set to $-10^{\circ}$. Fig. 5 shows that the detector line lies deep in the plasma core, passing from the high field side (HFS) to the low field side (LFS) through the plasma center. On the one hand, such probing scheme allows studying plasma potential and turbulence in the deep core and comparing fluctuations behavior at the LFS and HFS. On the other hand, the long path of primary trajectories in the plasma in combination with high plasma density $\left(\bar{n}_{\mathrm{e}}=0.710^{20} \mathrm{~m}^{-3}\right.$ in Globus-M2 [11]) means very strong beam attenuation leading to low signal-to-noise ratio. Fig. 6 also shows that the area of the plasma cross-section covered by the detector grid is rather small compared to the injection through the $90^{\circ}$ port.

Fig. 7 shows the detector line for $\mathrm{Cs}^{+}$probing beam with $\mathrm{E}_{\text {beam }}=40 \mathrm{keV}$ injected through the $78^{\circ}$ port. Fig. 8 shows the corresponding detector grid with $\mathrm{E}_{\text {beam }}=20 \ldots .45 \mathrm{keV}$. In a similar way to the case with the $90^{\circ}$ port, the angle $\alpha$ of the primary beam-line was set to $45^{\circ}$ in order to push detector lines deeper into the plasma, and the angle $\beta$ was set to $-5^{\circ}$. Fig. 7 shows the detector line for $\mathrm{Cs}^{+}$probing beam with $\mathrm{E}_{\text {beam }}=40 \mathrm{keV}$ injected through the $78^{\circ}$ port. Fig. 8 shows the corresponding detector grid with $\mathrm{E}_{\text {beam }}=20 \ldots 45 \mathrm{keV}$.
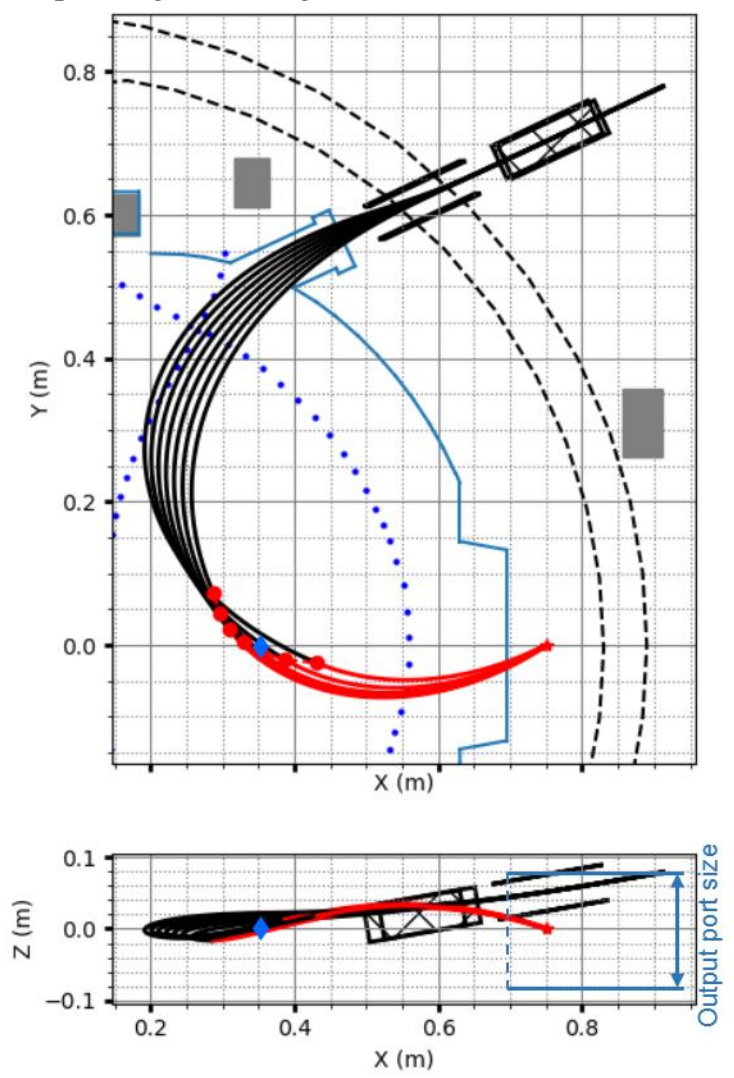

Fig. 5. HIBP detector line for the probing scheme 2 $\left(25^{\circ}\right.$ input port $), E_{\text {beam }}=40 \mathrm{keV}$. Primary beam-line angles are $\alpha=25^{\circ}, \beta=-10^{\circ}$. Top: side view, bottom: bottom view. Red star denotes the detection point, blue diamond denotes plasma center

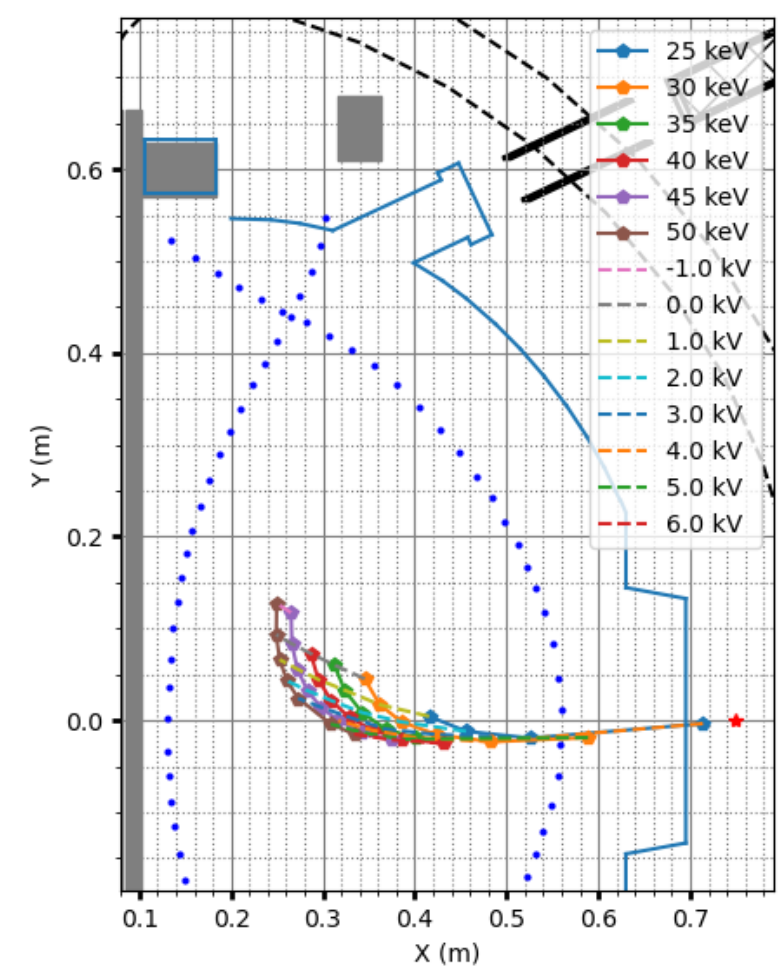

Fig. 6. Detector grid for the probing scheme 2 (25 input port). Primary beam-line angles are $\alpha=25^{\circ}, \beta=-10^{\circ}$ 

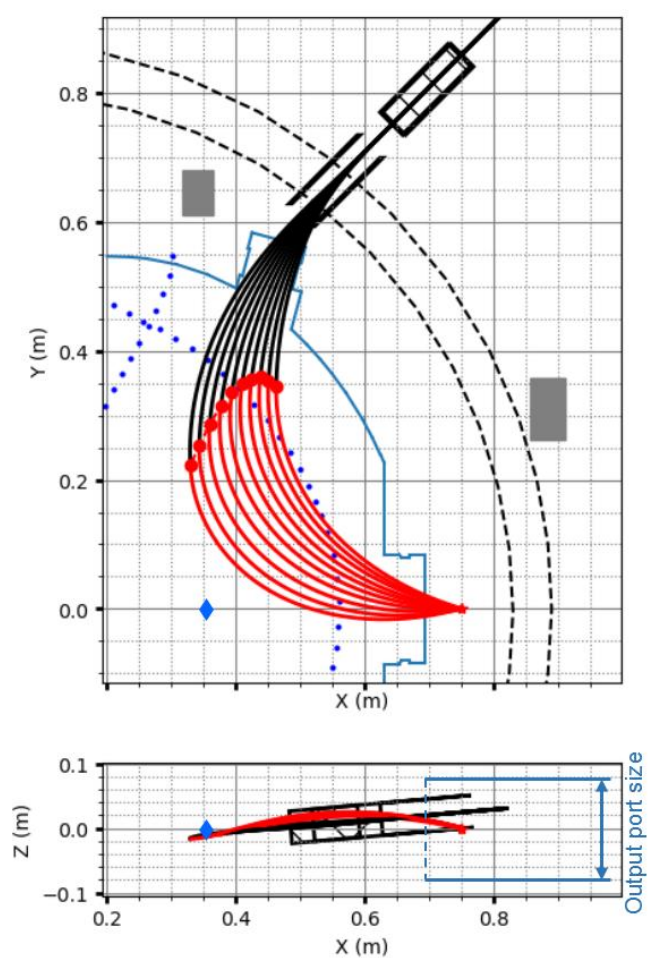

Fig. 7. HIBP detector line for the probing scheme 3 ( $78^{\circ}$ input port), $E_{\text {beam }}=40 \mathrm{keV}$. Primary beam-line angles are $\alpha=45^{\circ}, \beta=-5^{\circ}$. Top: side view, bottom: bottom view. Red star denotes the detection point, blue diamond denotes plasma center

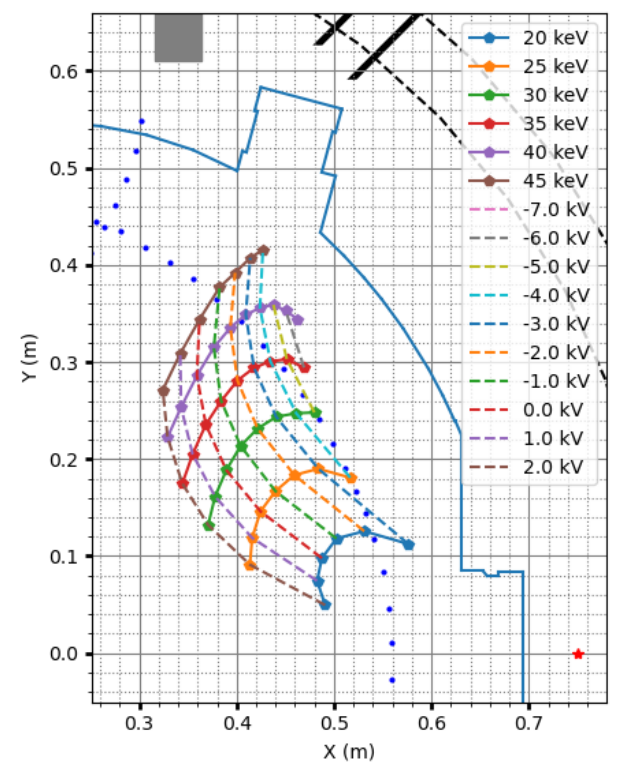

Fig. 8. Detector grid for the probing scheme 3 (78 input port). Primary beam-line angles are $\alpha=45^{\circ}, \beta=-5^{\circ}$

In a similar way to the case with the $90^{\circ}$ port, the angle- $\alpha$ of the primary beam-line was set to $45^{\circ}$ in order to push detector lines deeper into the plasma, and the angle $\beta$ was set to $-5^{\circ}$. The detector grid in Fig. 8 covers the widest area of the plasma cross-section with detector lines connecting plasma periphery with the plasma core up to $\mathrm{R}=0.32 \mathrm{~m}$. The $78^{\circ}$ port may be considered as the most suitable for the HIBP diagnostic.

\section{SECONDARY BEAM-LINE OPTIMIZATION}

The secondary beam-line with two sets of parallel plates similar to those in the primary beam-line is used to correct secondary trajectories and guide them to the energy analyzer [8]. To choose $\alpha$ and $\beta$ angles for the secondary beam-line Fig. 9 was plotted. It shows $\alpha$ and $\beta$ angles of secondary ions velocities at the detection point for $E_{\text {beam }}=20 \ldots 45 \mathrm{keV}$. The spreads for $\alpha$ and $\beta$ angles are $-15^{\circ}$ to $16^{\circ}$ and $13^{\circ}$ to $24^{\circ}$ respectively. Based on these values the vertical beam-line $\left(\alpha=0^{\circ}\right)$ with $\beta=20^{\circ}$ was chosen. As soon as the angle spreads are wide, the dimensions of the plates were increased up to $0.15 \times 0.1 \mathrm{~m}$ as well as the distance between plates $(0.1 \mathrm{~m})$

Fig. 10 shows the trajectories for $E_{\text {beam }}=40 \mathrm{keV}$ passing through the secondary beam-line. The voltages applied to the plates were selected to guide the secondary trajectories to the new detection point, which represents the entrance slit of the energy analyzer.
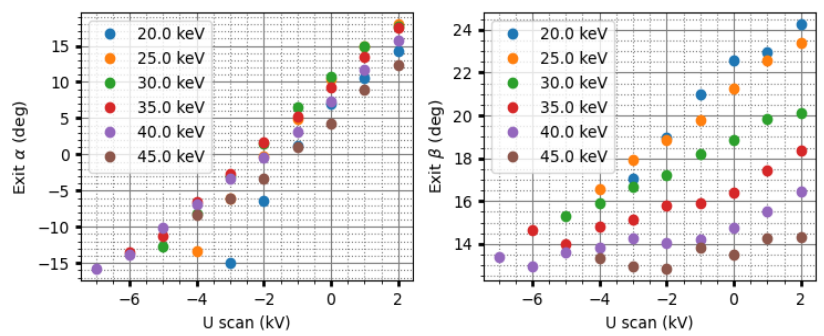

Fig. 9. $\alpha$ and $\beta$ angles of secondary particle velocities at the exit port. U scan is the voltage applied to the $\alpha$-plates of the primary beam-line, injection through the $78^{\circ}$ port. Primary beam-line angles are $\alpha=45^{\circ}, \beta=-5^{\circ}$

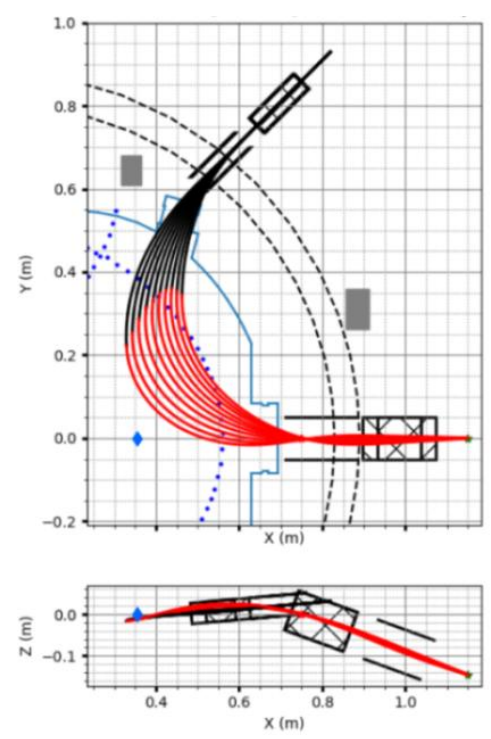

Fig. 10. HIBP detector line for the probing scheme 3 ( $78^{\circ}$ input port), $E_{\text {beam }}=40 \mathrm{keV}$, with the secondary beam-line. Primary beam-line angles are $\alpha=45^{\circ}$, $\beta=-5^{\circ}$. Secondary beam-line angles are $\alpha=0^{\circ}$, $\beta=20^{\circ}$. Top: side view, bottom: bottom view. Green star denotes the new detection point, blue diamond denotes plasma center 


\section{CONCLUSIONS}

The performed calculations show that HIBP is applicable for the upgraded Globus-M2 spherical tokamak. Three vacuum vessel ports were considered for HIBP location, the $78^{\circ}$ port was chosen as the most suitable due to the widest area of the plasma crosssection covered by the detector grid. Optimal angles for the primary $\left(\alpha=45^{\circ}, \beta=-5^{\circ}\right)$ and secondary $\left(\alpha=0^{\circ}\right.$, $\beta=20^{\circ}$ ) beam-lines were proposed.

\section{ACKNOWLEDGEMENTS}

This work was supported by Russian Science Foundation project 19-12-00312. A.V. Melnikov was partly supported by the Competitiveness Program of NRNU MEPhI.

\section{REFERENCES}

1. A.V. Melnikov. Applied and fundamental aspects of fusion science // Nature Physics.2016, v. 12, № 5, p. 86390.

2. F.C. Jobes, R.L. Hickok. A direct measurement of plasma space potential // Nuclear Fusion.1970, v. 10, № 2, p. 195-197.

3. Y.N. Dnestrovskij et al. Development of Heavy Ion Beam Probe Diagnostics // IEEE Transaction Plasma Science. 1994, v. 22, № 4, p. 310-331.

4. A.V. Melnikov et al. Heavy ion beam probingdiagnostics to study potential and turbulence in toroidal plasmas // Nuclear Fusion. 2017, v. 57, № 7, p. 072004. 5. A.V. Melnikov. Electric Potential in Toroidal Plasmas // Springer Nature Switzerland AG. 2019, p. 240.

6. A.V. Melnikov et al. Study of NBI-driven chirping mode properties and radial location by the heavy ion beam probe in the TJ-II stellarator // Nuclear Fusion. 2016, v. 56, № 11, p. 112019.
7. A.V. Melnikov et al. Detection and investigation of chirping Alfvén eigenmodes with heavy ion beam probe in the TJ-II stellarator // Nuclear Fusion. 2018, v. 58, № 8, p. 082019.

8. A.V. Melnikov et al. Heavy ion beam probe design and operation on the T-10 tokamak // Fusion Engineering and Design. 2019, v. 146, p. 850-853.

9. A.Shimizu et al. Density profile measurement with a heavy ion beam probe in a toroidal plasma of the compact helical system // Review of Scientific Instruments. 2018, v. 1, № 89, p. 113507.

10. P.O. Khabanov et al. Density profile reconstruction using HIBP in ECRH plasmas in the TJ-II stellarator // Journal of Instrumentation. 2019, v. 14, № 9, p. C09033.

11. V.B. Minaev et al. Spherical tokamak Globus-M2: design, integration, construction // Nuclear Fusion. 2017, v. 57, № 6, p. 066047.

12. V.B. Minaev et al. The Globus-M2 spherical tokamak: the first results // Journal of Physics: Conference Series. 2018, v. 1094, p. 012001.

13. A.V. Melnikov et al. Heavy ion beam probe systems for tight aspect ratio tokamaks // Review of Scientific Instruments. 1997, v. 68, № 1, p. 316-319.

14. M.A. Drabinskiy et al. Conceptual design of the heavy ion beam probe diagnostic for the T-15MD tokamak // Journal of Instrumentation. 2019, v. 14, № 11, p. C11027-C11027.

15. A.M. Ilinet et al. Probing ion trajectory simulations for the HIBP diagnostics at the T-15MD tokamak // Journal of Physics Conference Series. 2019, v. 1383, p. 012006.

16. V.B. Minaev et al. Magnetic System for the Upgraded Spherical Tokamak Globus-M2 // Proc. of 24th IAEA conf. San Dieg. 2012, p. ICC/P1-01.

Article received 05.10.2020

\title{
ПРОЕКТ ДИАГНОСТИКИ ПЛАЗМЫ ПУЧКОМ ТЯЖЕЛЫХ ИОНОВ ДЛЯ ТОКАМАКА ГЛОБУС-М2
}

\author{
Ф.О. Хабанов, А.В. Мельников, В.Б. Минаев, А.Д. Комаров
}

Рассмотрена возможность установки диагностики плазмы пучком тяжелых ионов на сферический токамак Глобус-М2. Для определения оптимального положения первичного и вторичного ионопроводов HIBP были проведены расчеты траекторий зондирующего пучка с учетом реальной геометрии установки. Рассмотрены три варианта входных патрубков и режим с тороидальным магнитным полем $\mathrm{B}_{\text {tor }}=0,7$ Тл и током плазмы $\mathrm{I}_{\mathrm{pl}}=0,5 \mathrm{MA}$. Выбраны оптимальная схема зондирования, обеспечивающая максимальную площадь покрытия вертикального сечения плазмы детекторной сеткой, и конфигурация вторичного ионопровода.

\section{ПРОЕКТ ДІАГНОСТИКИ ПЛАЗМИ ПУЧКОМ ВАЖКИХ ІОНІВ ДЛЯ ТОКАМАКА ГЛОБУС-М2}

\section{П.О. Хабанов, О.В. Мельніков, В.Б. Мінаев, О.Д. Комаров}

Розглянута можливість встановлення діагностики плазми пучком важких іонів на сферичний токамак Глобус-М2. Для визначення оптимального положення первинного і вторинного іонопроводів НІВР були проведені розрахунки траєкторій зондувального пучка 3 урахуванням реальної геометрії установки. Розглянуто три варіанти вхідних патрубків та режим 3 тороїдальним магнітним полем $\mathrm{B}_{\text {tor }}=0,7$ Тл та струмом плазми $\mathrm{I}_{\mathrm{pl}}=0,5$ МА. Обрано оптимальну схему зондування, що забезпечує максимальну площу покриття вертикального перерізу плазми детекторною сіткою, і конфігурація вторинного іонопроводу. 